\title{
Effect of Different Levels of Inorganic Nitrogen Fertilizer on Biomass, Seed Yield and Crude Protein Content of Rhodes Grass
}

\author{
Dawit Abate* Girma Chalchisa Daniel Wana \\ Adami Tulu Agricultural Research center, Batu, Ethiopia
}

\begin{abstract}
The experiment was conducted on-station at Adami Tulu Agricultural Research Center and Negele Arsi (FTC) sites with objective to assess the effect of different levels of inorganic nitrogen (N)-fertilizer on forage biomass, seed yield and crude protein (CP) performances of Rhodes grass. Different levels of inorganic $\mathrm{N}$ fertilizers were used as treatments. Accordingly a total of five treatments; Rhodes without fertilizer (T1), $23 \mathrm{~kg} / \mathrm{ha}$ of inorganic Nfertilizer (T2), $46 \mathrm{~kg} / \mathrm{ha}$ of inorganic N-fertilizer (T3), $69 \mathrm{~kg} / \mathrm{ha}$ of inorganic N-fertilizer (T4) and $92 \mathrm{~kg} / \mathrm{ha}$ of inorganic N-fertilizer (T5) were evaluated in Randomized Complete Block Design (RCBD) with three replications. The result indicated that the highest biomass, seed yield and CP content were obtained from the treatments fertilized with inorganic $\mathrm{N}$-fertilizers significantly $(\mathrm{p}<0.05)$ higher compared to the control treatment. The yield and $\mathrm{CP}$ contents increased with the increment of the rate of inorganic fertilizers. However, treatments with higher level of fertilizer application didn't produce significance yield and CP differences as compared to the lower level of fertilizer application. This clearly showed that applying fertilizers above the minimum levels $(23 \mathrm{~kg} / \mathrm{ha} \mathrm{N})$ didn't produce significantly higher yield and CP in this experiment. The lower yield and CP performance of the control/without fertilizer treatment showed that the experimental soil have not had enough nutrients to sustain optimal performance of Rhodes grass. Based on economic analysis results, the highest marginal rate of returns of 1.23 and 13.18 were produced for forage biomass and seed yield production, respectively, using inorganic Nfertilizer at the rate of $23 \mathrm{~kg} / \mathrm{ha}$. It indicated that this rate was the most economical among others for herbage biomass and seed yield production of Rhodes grass. Therefore, the optimum inorganic $\mathrm{N}$ fertilizer rate for small scale farmers of the study area with low cost of production and higher benefits was at a rate of $23 \mathrm{~kg} / \mathrm{ha}$.
\end{abstract}

Keywords: Biomass yield, Nitrogen fertilizer, Seed yield, Rhodes grass

DOI: $10.7176 / \mathrm{JNSR} / 10-10-01$

Publication date:May $31^{\text {st }} 2020$

\section{Introduction}

Livestock contribute significantly to food production directly via the provision of high value animal products, and indirectly by supporting crop production through draught power and manure. Moreover, they are important sources of income and store of wealth for smallholder farmers, thereby providing access to food. Despite enormous contribution of livestock to the livelihood of farmers and pastoralists, they are facing multifaceted problems, among which the major one is poor quantity and quality feed supply (Manaye et al., 2009). The major feed resources, natural pasture and crop residues, have low CP and voluntary intake. The area and productivity of grazing lands have greatly declined mainly due to expansion of cropping and consequent disappearance of valuable species, spread of unpalatable species and land degradation which are associated with overstocking and overgrazing (Ayana 2014) owing to congested grazing areas.

Thus, to solve the feed shortage and increase livestock production and productivity, it is necessary to promote the production of high biomass and quality of improved forages suitable to the environmental condition. Improved forage grasses are as one of the most important feed sources for grazing animals. Among forage grass species adapted and recommended so far for mid rift valley of Oromia, Rhodes grass (Chloris gayana) is found to be the best performed forage grass (Dawit et al., 2017). Rhodes grass is suitable to tropical and subtropical areas with rainfall ranging from $600-1600 \mathrm{~mm}$ per annum when grown on pastureland. It is grown in a wide range of soils; from clays to sandy loam (Valenzuela and Smith, 2002).

Nitrogen fertilizer is one of the most important fertilizers for encouraging grass growth and has great influence on growth and development of seed crops. Rhodes grass responds well to nitrogen fertilizer and the use of fertilizer are found to be important for improving the performances of the grasses (DeBona and Monteiro, 2010, Ahmed and Yassin 2013). Cowan et al. (1995) also stated that the increases in pasture yield of Rhodes grass are at a maximum when nitrogen applied to pastures. Herbage yield of Rhodes grass under mid rift valley condition is 5.2 ton DM/ha (ATARC annual report unpublished). This grass can yield up to $15 \mathrm{t} /$ ha with the application of nitrogen fertilizer (Getnet et al. 2003).

However, there is lack of information on the response of performance of Rhodes grass to inorganic nitrogen fertilizer application. Moreover, the optimum fertilizer rate that can maximize yield and quality of this grass species has not been established under conditions of the mid rift valley of Oromia. Hence, the study was initiated to assess the effect of different levels of inorganic $\mathrm{N}$-fertilizer on agronomic, yield and quality performances of Chloris gayana in mid rift valley of Oromia. 


\section{Materials and methods \\ Study area}

The experiment was conducted on-station at Adami Tulu and Negele Arsi FTC sites for three consecutive years (2016-2018 E.C. Adami Tulu and Negele Arsi districts are located in the mid rift valley of Oromia, at about 167 and $225 \mathrm{~km}$, respectively, south of Addis Ababa on the way to Hawasa. Adami Tulu research center lies at latitude of $7^{\circ} 9^{\prime} \mathrm{N}$ and $38^{\circ} 7^{\prime} \mathrm{E}$ longitude. Its altitude is about 1650 meters above sea level (m.a.s.l). It has an average annual rainfall of $727.1 \mathrm{~mm}$, whereas the average annual minimum and maximum temperatures of the area during the study period were $11.8^{\circ} \mathrm{C}$ and $28.3^{\circ} \mathrm{C}$, respectively (ATARC metrology data, 2015 - 2017). Negele Arsi district is located at $38^{\circ} 25^{\prime} \mathrm{E}$ to $38^{\circ} 54^{\prime} \mathrm{E}$ longitude and $07^{\circ} 09^{\prime}$ to $07^{\circ} 41^{\prime} \mathrm{N}$ latitude. It has borderlines with Southern Nations, Nationalities and Peoples Regional State (CSA, 2017/18). Negele Arsi district is grouped into three climatic zones based on altitude. These are low, mid and high altitude ranging from 1500- 3070 masl. It has a bimodal rainfall pattern with a short rainy season from March to May and the main rainy season from late June to September. The dry season in the area is mostly from October to February. The mean annual rainfall of the district is $825 \mathrm{~mm}$ while the annual temperature varies within a range of 16 and $25^{\circ} \mathrm{C}(\mathrm{CSA}, 2017 / 18)$.

\section{Experimental treatments and design}

Adapted Rhodes grass (Chloris gayana Cv. Masaba) was established on a well prepared seedbed using a recommended seeding rate of $15 \mathrm{~kg} /$ ha. Different rates of inorganic $\mathrm{N}$-fertilizers were used in the experiment. A total of five treatments, namely, Rhodes without fertilizer (T1), $23 \mathrm{~kg} / \mathrm{ha}$ of inorganic N-fertilizer (T2), $46 \mathrm{~kg} / \mathrm{ha}$ of inorganic $\mathrm{N}$ fertilizer (T3), $69 \mathrm{~kg} / \mathrm{ha}$ of inorganic $\mathrm{N}$ fertilizer (T4) and $92 \mathrm{~kg} / \mathrm{ha}$ of inorganic $\mathrm{N}$ fertilizer (T5) were used. Treatments arrangements were done based on the recommended inorganic N-fertilizer for Rhodes grass production by different authors (ESGPIP 2008, Getnet et al. 2003). The treatments were laid out in RCBD with three replications. Nitrogen fertilizer was splitted into two so that one half was applied at planting and the balance at tillering. Phosphorous fertilizer was applied at the rate of $46 \mathrm{~kg}_{2} \mathrm{O}_{5} /$ ha to all inorganic nitrogen source (UREA) plots.

All necessary data including planting date, days to $50 \%$ flowering, plant height, total forage biomass, dry matter and seed yield were recorded. Forage yield was estimated by harvesting the grasses at $50 \%$ flowering stage, which is the recommended harvesting stage for perennial grasses to compromis herbage yield and quality. The mature inflorescences were harvested $10-15 \mathrm{~cm}$ below the panicle; then sun dried, piled for few days and manually threshed and cleaned to estimate seed yields. Herbage samples were dried to constant weight using forced airdrying oven to determine the dry matter using methods described by AOAC (2000). Total nitrogen was determined following Kjeldahl procedure as described by Cottenie (1980).

\section{Partial budget analysis}

Simple partial budget analysis was employed for economic analysis at different levels of inorganic $\mathrm{N}$ fertilizer application for biomass and seed yield. The potential response of the grass towards the added fertilizer and price of fertilizers ultimately determine the economic feasibility of fertilizer application (CIMMYT, 1988). To estimate the total costs, mean prices of Urea and DAP was collected at the time of planting and market price of Rhodes grass herbage and seed were also taken at harvest. The economic analysis was based on the formula developed by CIMMYT (1988) and given as follows:

Gross average biomass and seed yield $\left(\mathrm{kgha}^{-1}\right)(\mathrm{AvY})$ : is an average yield of each treatment.

Adjusted yield (AjY):is the average yield adjusted downward by a $10 \%$ to reflect the difference between the experimental yield and yield of farmers.AjY $=A v Y^{*}(1-0.1)$

Gross field benefit (GFB): was computed by multiplying field/farm gate price that farmers receive for the grass when they sale it as adjusted yield. $\mathrm{GFB}=\mathrm{AjY} \mathrm{F}^{*}$ field/farm gate price for the grass

Total cost: is the cost of UREA and DAP were considered. Their prices was based on the price during experimental periods. The costs of other inputs and production practices such as labor cost for land preparation, planting, weeding and harvesting were assumed to remain the same or were insignificant among treatments.

Net benefit (NB): was calculated by subtracting the total costs from gross field benefits for each treatment. NB $=\mathrm{GFB}-$ total cost

Marginal return (MR): is the measure of increasing in return by increasing input

Marginal rate of return (MRR \%): was calculated by dividing change in net benefit by change in cost.

$$
\operatorname{MRR}=\frac{\Delta N B}{\Delta \mathrm{TC}}
$$

According to CIMMYT (1988), the minimum acceptable marginal rate of return (MRR) should be 1.0. If both net income and variable costs increase, the rate of return should be looked at, the greater increase in net income and the higher rate of return, the more economically an alternative technology is, hence, the new technology should be accepted only if its rate of return is higher than 1.0 . 


\section{Statistical analysis}

The collected agronomic, herbage DM and seed yield data were subjected to analysis of variance using the SAS statistical procedures. Means were separated using least significant difference (LSD) at 5\% significant level.

\section{Result and Discussions}

The results of agronomic performance of Rhodes grass tested for different levels of $\mathrm{N}$ - fertilizers are presented in table 1. The result indicated that different levels of inorganic $\mathrm{N}$-fertilizer were significantly $(\mathrm{p}<0.05)$ increased lant height of Rhodes grass. The longest mean plant height $(90.38 \mathrm{~cm})$ was recorded from treatment with $\mathrm{N}$-fertilizer of $69 \mathrm{~kg} /$ ha while the shortest $(73.98 \mathrm{~cm})$ plant height was recorded from the control treatment. Different authors have found different results regarding the effect of $\mathrm{N}$ - fertilizer on plant height. Brima (2007) and Abedelrahman (2007) stated that mean plant height of Rhodes grass were not significantly affected by different fertilizer levels while Saad (2009) found a significant effect of nitrogen fertilizer on mean plant height. In other researches, increase in nitrogen fertilization significantly increased grass height (Adam, 2004 and Gasim, 2001, Mohammed, 1990).

On the other hand, there was no significant $(\mathrm{p}>0.05)$ differences in plot cover and days to $50 \%$ flowering among the tested treatments. Data on days to $50 \%$ flowering indicated that the different level of N-fertilizer didn't produced significant $(\mathrm{p}>0.05)$ variations among the treatments. However, it takes longer mean of days $(91.13)$ at Negele Arsi site to reach 50\% flowering stage as compared to Adami Tulu site (70.33) probably due to the agroecology differences as hot climate prompted early maturity of the crops at Adami Tulu site.

Table 1. Mean plot cover, plant height and days to 50\% flowering of Rhodes grass in response to different levels of inorganic Nitrogen fertilizers

\begin{tabular}{|l|c|c|c|c|c|c|c|c|c|}
\hline Treatments & \multicolumn{3}{|c|}{ Plot cover (\%) } & \multicolumn{3}{c|}{ Plant height (cm) } & \multicolumn{3}{c|}{ Days to 50\% flowering } \\
\hline & $\begin{array}{c}\text { Adami } \\
\text { Tulu }\end{array}$ & $\begin{array}{c}\text { Negele } \\
\text { Arsi }\end{array}$ & Mean & $\begin{array}{c}\text { Adami } \\
\text { Tulu }\end{array}$ & $\begin{array}{c}\text { Negele } \\
\text { Arsi }\end{array}$ & Mean & $\begin{array}{c}\text { Adami } \\
\text { Tulu }\end{array}$ & $\begin{array}{c}\text { Negele } \\
\text { Arsi }\end{array}$ & Mean \\
\hline $\begin{array}{l}\text { Without } \\
\text { fertilizer }\end{array}$ & 75.08 & 80.75 & 77.92 & $66.30 \mathrm{~b}$ & $81.66 \mathrm{~b}$ & $73.98 \mathrm{~b}$ & 72.33 & 90.33 & 81.83 \\
\hline $23 \mathrm{~kg} / \mathrm{ha}$ & 70.00 & 90.08 & 80.04 & $80.80 \mathrm{a}$ & $87.33 \mathrm{ab}$ & $84.06 \mathrm{a}$ & 71.66 & 91.33 & 81.50 \\
\hline $46 \mathrm{~kg} / \mathrm{ha}$ & 73.75 & 85.33 & 79.54 & $81.33 \mathrm{a}$ & $92.16 \mathrm{a}$ & $86.75 \mathrm{a}$ & 70.66 & 91.00 & 80.83 \\
\hline $69 \mathrm{~kg} / \mathrm{ha}$ & 87.75 & 79.33 & 83.54 & $91.26 \mathrm{a}$ & $89.50 \mathrm{a}$ & $90.38 \mathrm{a}$ & 67.66 & 91.33 & 79.50 \\
\hline $92 \mathrm{~kg} / \mathrm{ha}$ & 79.50 & 87.50 & 83.50 & $85.70 \mathrm{a}$ & $92.00 \mathrm{a}$ & $88.85 \mathrm{a}$ & 69.33 & 90.66 & 80.0 \\
\hline Mean & $\mathbf{7 7 . 2 2}$ & $\mathbf{8 4 . 6 0}$ & $\mathbf{8 0 . 9 1}$ & $\mathbf{8 1 . 0 8}$ & $\mathbf{8 8 . 5 3}$ & $\mathbf{8 4 . 8 1}$ & $\mathbf{7 0 . 3 3}$ & $\mathbf{9 1 . 1 3}$ & $\mathbf{8 0 . 7 3}$ \\
\hline CV & $\mathbf{1 3 . 6 4}$ & $\mathbf{1 0 . 2 1}$ & $\mathbf{1 3 . 3 4}$ & $\mathbf{9 . 5 8}$ & $\mathbf{4 . 6 8}$ & $\mathbf{8 . 9 3}$ & $\mathbf{3 . 9 5}$ & $\mathbf{1 . 8 5}$ & $\mathbf{1 4 . 3 8}$ \\
\hline LSD (5\%) & $\mathbf{N S}$ & $\mathbf{N S}$ & $\mathbf{N S}$ & $\mathbf{1 4 . 1 3}$ & $\mathbf{7 . 5 4}$ & $\mathbf{9 . 0}$ & $\mathbf{N S}$ & $\mathbf{N S}$ & $\mathbf{N S}$ \\
\hline
\end{tabular}

${ }^{1} \mathrm{LSD}=$ Least significant difference. $\mathrm{CV}=\mathrm{Coefficient}$ of variation, $\mathrm{NS}=$ Non significant

${ }^{2}$ Figure having the same letters with in column are not significantly differ, while values followed by different letter (s) are significantly differ

Herbage dry matter, seed yield and CP recorded from application of different inorganic $\mathrm{N}$ fertilizer levels are presented in table 2 . At both sites, dry matter, seed yield and CP content were significantly $(\mathrm{p}<0.05)$ the higher for the $\mathrm{N}$ fertilizer applied treatments than the control. The result of the combined sites indicated that the maximum mean dry matter (13.55t/ha) and seed yield (501.28kg/ha) values were recorded from the higher level (92kg/ha) of $\mathrm{N}$ fertilizer treatment. On the other hands the highest mean $(11.75 \%) \mathrm{CP}$ value was recorded for the lower rate of $\mathrm{N}$ fertilizer treatment. The control treatment performed the least in all parameters. Previous studies also found that Rhodes grass responded well to nitrogen fertilizer (Valenzuela and smith, 2002). The higher yield obtained from fertilized Rhodes grass could be due to the improvement in soil nutrients. On the other hand, the lower yield and CP obtained from control/without fertilizer treatment showed that the experimental soils have not had enough nutrients to sustain optimal performance of Rhodes grass. Hence, the biomass and seed production as well as CP depends on contribution of $\mathrm{N}$ which, in turn, is dependent on the amount of organic matter in the soil. Borhan and Hago (2000) also stated that nitrogen plays an important role in plant growth and physiological processes, as it enters all enzymes composition and enhances vegetative growth and yield.

The trend of dry matter and see yield increment indicates that the yield increased somewhat with the increment of inorganic $\mathrm{N}$ fertilizer rates. However, the tested treatments with inorganic $\mathrm{N}$-fertilizers were not significantly different in yield and $\mathrm{CP}$ performance among themselves. So, increasing quantities of inorganic N-fertilizer above $23 \mathrm{~kg} / \mathrm{ha}$ didn't significantly increased dry matter, seed yield and CP contents of Rhodes grass. The significant differences were observed between the control (without fertilizer) and treatments with different levels of fertilizer application. These results made evident that the input of $\mathrm{N}$-fertilizer only from the soil does not allow the grasses to express their biological potential. Moreover, the treatments with higher level of fertilizer application didn't produce significant yield and CP differences as compared to the lower levels of fertilizer application. This clearly showed that applying fertilizers above the minimum levels didn't produce significantly higher dry matter yield in 
this experiment. The high value of $\mathrm{CP}$ content recorded for the fertilizer applied treatments as compared to unfertilized/control treatment could be due to the addition of $\mathrm{N}$ from applied inorganic fertilizer.

Generally, the better yield and CP performance were observed at Negele Arsi as compared to Adami Tulu site. The mean DM (13.78t/ha), seed yield $(490.59 \mathrm{~kg} / \mathrm{ha})$ and CP $(11.50 \%)$ were recorded at Negele Arsi site while at Adami Tulu 11.34t/ha, 405.48kg/ha and 9.01\% values, respectively. The Better yield and CP were recorded for the tested treatments at Negele Arsi as compared to Adami Tulu site which could be mainly due to better soil fertility and soil moisture in the former study area. Climatic conditions are one of the factors that determine herbage DM production of the grasses (Debele et al., 2001). Other finding also confirmed that the variation in climatic and soil type of the experimental area and/or their interactions could also result in yield and CP differences of the forage grasses (Diriba et al., 2014).

Table 2. Dry matter, seed yield and crude protein performance of Rhodes grass in response to different levels of inorganic Nitrogen fertilizers

\begin{tabular}{|l|c|c|c|c|c|c|c|c|c|}
\hline Treatments & \multicolumn{3}{|c|}{ DM yield (t/ha) } & \multicolumn{3}{c|}{ Seed yield (kg/ha) } & \multicolumn{3}{c|}{ Crude Protein (\%) } \\
\hline & $\begin{array}{c}\text { Adami } \\
\text { Tulu }\end{array}$ & $\begin{array}{c}\text { Negele } \\
\text { Arsi }\end{array}$ & Mean & $\begin{array}{c}\text { Adami } \\
\text { Tulu }\end{array}$ & $\begin{array}{c}\text { Negele } \\
\text { Arsi }\end{array}$ & Mean & $\begin{array}{c}\text { Adami } \\
\text { Tulu }\end{array}$ & $\begin{array}{c}\text { Negele } \\
\text { Arsi }\end{array}$ & Mean \\
\hline $\begin{array}{l}\text { Without } \\
\text { fertilizer }\end{array}$ & $9.43 \mathrm{~b}$ & $11.56 \mathrm{~b}$ & $10.49 \mathrm{~b}$ & $294.80 \mathrm{~b}$ & $332.96 \mathrm{~b}$ & $313.88 \mathrm{~b}$ & $6.60 \mathrm{~b}$ & $6.80 \mathrm{~b}$ & $6.70 \mathrm{~b}$ \\
\hline $23 \mathrm{~kg} / \mathrm{ha}$ & $11.41 \mathrm{a}$ & $13.79 \mathrm{a}$ & $12.60 \mathrm{a}$ & $392.68 \mathrm{a}$ & $502.33 \mathrm{a}$ & $447.5 \mathrm{a}$ & $9.95 \mathrm{a}$ & $13.54 \mathrm{a}$ & $11.75 \mathrm{a}$ \\
\hline $46 \mathrm{~kg} / \mathrm{ha}$ & $11.74 \mathrm{a}$ & $14.29 \mathrm{a}$ & $13.02 \mathrm{a}$ & $422.00 \mathrm{a}$ & $510.75 \mathrm{a}$ & $466.39 \mathrm{a}$ & $10.00 \mathrm{a}$ & $13.04 \mathrm{a}$ & $11.52 \mathrm{a}$ \\
\hline $69 \mathrm{~kg} / \mathrm{ha}$ & $11.78 \mathrm{a}$ & $14.49 \mathrm{a}$ & $13.14 \mathrm{a}$ & $450.62 \mathrm{a}$ & $539.37 \mathrm{a}$ & $495.00 \mathrm{a}$ & $9.00 \mathrm{a}$ & $11.63 \mathrm{a}$ & $10.32 \mathrm{a}$ \\
\hline $92 \mathrm{~kg} / \mathrm{ha}$ & $12.34 \mathrm{a}$ & $14.75 \mathrm{a}$ & $13.55 \mathrm{a}$ & $467.33 \mathrm{a}$ & $535.22 \mathrm{a}$ & $501.28 \mathrm{a}$ & $9.51 \mathrm{a}$ & $12.48 \mathrm{a}$ & $10.99 \mathrm{a}$ \\
\hline Mean & $\mathbf{1 1 . 3 4}$ & $\mathbf{1 3 . 7 8}$ & $\mathbf{1 2 . 5 6}$ & $\mathbf{4 0 5 . 4 8}$ & $\mathbf{4 9 0 . 5 9}$ & $\mathbf{4 4 4 . 8 1}$ & $\mathbf{9 . 0 1}$ & $\mathbf{1 1 . 5 0}$ & $\mathbf{1 0 . 2 5}$ \\
\hline CV & $\mathbf{1 7 . 0}$ & $\mathbf{1 5 . 0 3}$ & $\mathbf{1 8 . 4 2}$ & $\mathbf{2 4 . 7 4}$ & $\mathbf{1 4 . 4 5}$ & $\mathbf{2 1 . 4 5}$ & $\mathbf{1 4 . 3 5}$ & $\mathbf{1 4 . 6 1}$ & $\mathbf{1 9 . 6 8}$ \\
\hline LSD (5\%) & $\mathbf{1 . 8 4}$ & $\mathbf{2 . 0 4}$ & $\mathbf{1 . 5 3}$ & $\mathbf{9 5 . 5 9}$ & $\mathbf{6 7 . 5 5}$ & $\mathbf{6 3 . 2 4}$ & $\mathbf{2 . 3 5}$ & $\mathbf{3 . 0 5}$ & $\mathbf{2 . 4 0}$ \\
\hline
\end{tabular}

${ }^{1} \mathrm{LSD}=$ Least significant difference. $\mathrm{CV}=$ Coefficient of variation, $\mathrm{NS}=$ Non significant

${ }^{2}$ Figure having the same letters with in column are not significantly differ, while values followed by different letter (s) are significantly differ

\section{Partial Budgeting Analysis}

Partial budget analysis result for herbage biomass and seed production of Rhodes grass in response to different $\mathrm{N}$ fertilizer levels are presented in table 3 and table 4, respectively. The cost benefit analysis for Rhodes biomass production revealed that the highest total cost (7730 birr/ha) was recorded from the maximum level (92kg/ha) of inorganic $\mathrm{N}$ fertilizer while the lowest total cost was from the control (without fertilizer) treatment. On the other hand, the highest (22793.75 birr/ha) net benefit was obtained from the medium level $(46 \mathrm{~kg} / \mathrm{ha})$ of inorganic $\mathrm{N}$ fertilizer. However, the highest marginal rate of returns (1.23) was recorded from treatment with $23 \mathrm{~kg} / \mathrm{ha}$ of inorganic $\mathrm{N}$ fertilizer while the other $\mathrm{N}$ fertilizer rates showed MRR below 1 and negative value. The values of MRR recorded below 1 for the other inorganic $\mathrm{N}$ fertilizer rates could be due to the increase in the total input costs and reduction in the revenue from the treatments as compared to the lowest $(23 \mathrm{~kg} / \mathrm{ha})$ of $\mathrm{N}$-fertilizer application level. Hence, the treatment with inorganic $\mathrm{N}$ fertilizer rate of $23 \mathrm{~kg} / \mathrm{ha}$ was found to be the best profitable while the other treatments with MRR below would not be considered. 
Table 3. Partial budget analysis of different levels of inorganic nitrogen fertilizers for forage biomass production of Rhodes grass

\begin{tabular}{|l|c|c|c|c|c|}
\hline Descriptions & $\begin{array}{c}\text { Without } \\
\text { fertilizer }\end{array}$ & $\begin{array}{c}\mathbf{2 3} \\
\mathbf{k g} / \mathbf{h a}\end{array}$ & $\mathbf{4 6} \mathbf{~ k g} / \mathbf{h a}$ & $\begin{array}{c}\mathbf{6 9} \\
\mathbf{k g} / \mathbf{h a}\end{array}$ & $\mathbf{9 2} \mathbf{~ k g} / \mathbf{h a}$ \\
\hline Gross income (Birr) & & & & & \\
\hline Average forage DM yield (ton/ha) & 10.495 & 12.6 & 13.015 & 13.135 & 13.545 \\
\hline Adjusted forage DM yield (ton/ha) & 9.4455 & 11.34 & 11.7135 & 11.8215 & 12.1905 \\
\hline Sale price of forage (Birr/ton) & 2500 & 2500 & 2500 & 2500 & 2500 \\
\hline Sale revenue of forage (Birr) & 23613.75 & 28350 & 29283.75 & 29553.75 & 30476.25 \\
\hline Input costs (Birr/ha) & & & & & \\
\hline Rhodes seed & 3750 & 3750 & 3750 & 3750 & 3750 \\
\hline UREA (12birr/kg) & & 600 & 1200 & 1800 & 2400 \\
\hline DAP (15 birr/kg) (transportation and/or & & 1500 & 1500 & 1500 & 1500 \\
\hline $\begin{array}{l}\text { Variable costs } \\
\text { preparation) }\end{array}$ & $\mathbf{3 7 5 0}$ & $\mathbf{5 8 7 0}$ & $\mathbf{6 4 9 0}$ & $\mathbf{7 1 1 0}$ & $\mathbf{7 7 3 0}$ \\
\hline Total input costs & $\mathbf{1 9 8 6 3 . 7 5}$ & $\mathbf{2 2 4 8 0}$ & $\mathbf{2 2 7 9 3 . 7 5}$ & $\mathbf{2 2 4 4 3 . 7 5}$ & $\mathbf{2 2 7 4 6 . 3}$ \\
\hline Net benefit (Birr) & & 2616.25 & 313.75 & $\mathbf{- 3 5 0}$ & 302.5 \\
\hline $\begin{array}{l}\text { Change in net benefits between two } \\
\text { consecutive treatments }\end{array}$ & & 2120 & 620 & 620 & 620 \\
\hline $\begin{array}{l}\text { Change in total variable input costs between } \\
\text { two consecutive treatments }\end{array}$ & & $\mathbf{1 . 2 3}$ & $\mathbf{0 . 5 1}$ & $\mathbf{- 0 . 5 6}$ & $\mathbf{0 . 4 8}$ \\
\hline Marginal rate of return & & & 40 & 80 \\
\hline
\end{tabular}

The cost benefit analysis for Rhodes seed production using different levels of inorganic $\mathrm{N}$ fertilizer levels is indicated in table 4 . The highest net benefit of $105054 \mathrm{Birr} / \mathrm{ha}$, was recorded from the highest $(92 \mathrm{~kg} / \mathrm{ha})$ inorganic $\mathrm{N}$ fertilizer level. However, the marginal rate of returns for the treatments revealed that the highest value (13.18) was recorded from the application of $23 \mathrm{~kg} / \mathrm{ha}$ of $\mathrm{N}$-fertilizer level. The maximum values of MRR recorded from inorganic $\mathrm{N}$-fertilizer at $23 \mathrm{~kg} / \mathrm{ha}$ rates showed the significant contribution of the $\mathrm{N}$-fertilizer rates on the soil fertility improvement for optimum and cost effective Rhodes biomass and seed yield production. Hence, the highest marginal rate of returns produced from $23 \mathrm{~kg} /$ ha of inorganic $\mathrm{N}$-fertilizer rates for biomass and seed yield production indicated that these rates were the most economical among the other rates for herbage biomass and seed production from Rhodes grass at the study area.

Table 4. Partial budget analysis of different levels of inorganic nitrogen fertilizers for seed production of Rhodes grass

\begin{tabular}{|l|c|c|c|c|c|}
\hline Descriptions & $\begin{array}{l}\text { Without } \\
\text { fertilizer }\end{array}$ & $\mathbf{2 3} \mathbf{~ k g} / \mathbf{h a}$ & $\mathbf{4 6} \mathbf{~ k g} / \mathbf{h a}$ & $\mathbf{6 9} \mathbf{~ k g} / \mathbf{h a}$ & $\mathbf{9 2} \mathbf{~ k g} / \mathbf{h a}$ \\
\hline Gross income (Birr) & & & & & \\
\hline Average seed yield (kg/ha) & 313.88 & 447.515 & 466.375 & 494.985 & 501.26 \\
\hline Adjusted seed yield (kg/ha) & 282.492 & 402.7635 & 419.7375 & 445.4865 & 451.134 \\
\hline Sale price (birr/kg)=250 & 250 & 250 & 250 & 250 & 250 \\
\hline Sale revenue (Birr) & 70623 & 100690.88 & 104934.38 & 111371.63 & 112783.5 \\
\hline Input costs (Birr/ha) & & & & & \\
\hline Rhodes seed & 3750 & 3750 & 3750 & 3750 & 3750 \\
\hline UREA (12birr/kg) & & 600 & 1200 & 1800 & 2400 \\
\hline DAP (15 birr/kg) & & 1500 & 1500 & 1500 & 1500 \\
\hline $\begin{array}{l}\text { Variable costs (transportation and/ or } \\
\text { preparation) }\end{array}$ & & 20 & 40 & 60 & 80 \\
\hline Total input costs & $\mathbf{3 7 5 0}$ & $\mathbf{5 8 7 0}$ & $\mathbf{6 4 9 0}$ & $\mathbf{7 1 1 0}$ & $\mathbf{7 7 3 0}$ \\
\hline Net benefit (Birr) & $\mathbf{6 6 8 7 3}$ & $\mathbf{9 4 8 2 0 . 8 7 5}$ & $\mathbf{9 8 4 4 4 . 3 7 5}$ & $\mathbf{1 0 4 2 6 1 . 6 3}$ & $\mathbf{1 0 5 0 5 4}$ \\
\hline $\begin{array}{l}\text { Change in net benefits between two } \\
\text { consecutive treatments }\end{array}$ & & 27947.875 & 3623.5 & 5817.25 & 791.875 \\
\hline $\begin{array}{l}\text { Change in total variable input costs } \\
\text { between two consecutive treatments }\end{array}$ & & 2120 & 620 & 620 & 620 \\
\hline Marginal rate of return & & $\mathbf{1 3 . 1 8}$ & $\mathbf{5 . 8 4}$ & $\mathbf{9 . 3 8}$ & $\mathbf{1 . 2 7}$ \\
\hline
\end{tabular}

\section{Conclusions}

The study indicated that all treatments with $\mathrm{N}$ fertilizers have produced better dry matter, seed yield and $\mathrm{CP}$ content as compared to the non-fertilized (control) treatment. However, the treatments with inorganic $\mathrm{N}$ fertilizers were 
not significantly different in dry matter and seed yield production among themselves. Hence, applying inorganic $\mathrm{N}$ fertilizer above $23 \mathrm{~kg} /$ ha didn't produce significantly higher dry matter, seed yield and $\mathrm{CP}$ content. Economic analysis results also showed that benefits from Rhodes grass can be increased through application of inorganic Nfertilizers. However, the highest marginal rate of returns produced from $23 \mathrm{~kg} /$ ha inorganic $\mathrm{N}$-fertilizer indicated that this rate is the most economical among the others for herbage biomass and seed production. Hence, it is logical to recommend inorganic $\mathrm{N}$-fertilizer at the rate of $23 \mathrm{~kg} /$ ha for optimum dry matter and seed yield and CP improvement of Rhodes grass at the study area.

\section{References}

Cowan, R.T; Lowe.K.F; Upton, P.C. And Bowdler, T.M. (1995).

Nitrogen fertilized grass in a subtropical dairy system 3. Effect of stocking rate on the response to nitrogen fertiliser. Australian Journal of Experimental Agricultural. Volume 35:145-151.

Abdelrahman, F.I. 2007. Effect Seed Rate and NPK Fertilization on Growth and Yield of Forage Quality of Rhodes Grass (Chloris gayana L. Kunth). M.Sc. Thesis. Faculty of Agriculture, University of Khartoum, Sudan.

Adam, M.Y. 2004. Effect of Seed Rate and Nitrogen on Growth and Yield of Teff Grass (Eragrostis teff, zucc.) Trotter MSc. Thesis. Faculity of Agriculture, University of Khartum, Sudan

Ahmed M. and Yassin M. 2013. Effect of Organic and Inorganic Fertilizers on Proximate Analysis of Rhodes Grass (Chloris gayana L. Knuth.)Universal Journal of Plant Science. 1(4): 1 37-140.

AOAC, 2000. AOAC Method 965, 17. Photometric method. CAS-7723-14-0.

ATARC (Adami Tulu Agricultural Research Center) 2017. Annual report (Unpublished)

ATARC (Adami Tulu Agricultural Research Center) 2017. Metrology data (Unpublished)

Ayana Angasa 2014. Effects of grazing intensity and bush encroachment on herbaceous species and rangeland condition in Southern Ethiopia. Journal of Land degradation and development

Brima, F.I.A. 2007. Effect of Seed Rate and NPK Fertilization on Growth, Yield and Forage Quality of Rhodes grass (Chloris gayana L. Kunth). M.Sc. Thesis. Faculty of Agriculture, University of Khartoum, Sudan.CIMMYT (International Maize and Wheat Improvement Centre). 1988. From agronomic data to farmer recommendations: Economic training manual. Completely revised edition. CIMMYT, Mexico.

Borhan, H. And Hago, T.E. 2000. Principle of Crop Production. University of Khartoum Printing Press, Sudan (Arabic addition).

CIMMYT. 1988. From agronomic data to farmer recommendations: An economics training manual. Mexico, CIMMYT.

Cottenie, A. (1980). Soil and plant testing as a basis of fertilizer recommendations. Food and Agriculture Organization of the United Nations, Rome, Italy

Cowan, R.T; Lowe. K.F; Upton, P.C and Bowdler, T.M. 1995. Nitrogen fertilized grass in a subtropical dairy system 3. Effect of stocking rate on the response to nitrogen fertilizer. Australian Journal of Experimental Agriculture. Volume 35:145-151.

CSA,2017/18. Agricultural Sample Survey Volume II: report on livestock and livestock characteristics (Private peasant holdings). Central Statistics Authority (CSA), Statistical Bulletin 100. Addis Ababa, Ethiopia.

Dawit Abate, Usman Semman, Nabi Husen, Lalisa Diriba, Belete Shenkute, Fikadu Nemera, Meseret Tilahun and Abule Ebro 2017. Yield and Agronomic Performance of Different Forage Grasses and Legume Species for Forage Production in the Mid Rift Valley of Oromia. In: Proceedings of Review Workshop on Completed Research Activities of Livestock Research Directorate held at Adami Tulu Agricultural Research Center, Adami Tulu, Ethiopia 17-21 November 2015, Oromia Agricultural Research Institute (OARI), Finfinne, Ethiopia. 247 pp.

Debele, T. and Friessen, D.K 2001. Effect of enriching farmyard manure with mineral fertilizer on grain yield of maize at Bako, western Ethiopia. Seventh Eastern and Southern African Maize conference 11th-15th February. 335-337 pp.

DeBona, F.D.; Monteiro, F.A. 2010. The development and production of leaves and tillers by Marandu palisadegrass fertilized with nitrogen and fertilization. Tropical Grasslands, v.44, p.192-201

Diriba G, Mekonnen H, Ashenafi M, Adugna T., 2014. Biomass yield potential and nutritive value of selected Alfalfa (Medicagosativa.) cultivars grown under tepid to cool sub-moist agro-ecology of Ethiopia. E3 Journal of Agricultural Research and Development Vol. 4(1). Pp. 007-014, January, 2014.

ESGPIP (Ethiopian sheep and Goats Productivity Improvement program), 2008. Sheep and goats production handbook for Ethiopia, Branna printing enterprise. Ethiopia. 345p.

Gasim, S.A. 2001. Effect of Nitrogen, Phosphorus and seed rate on Growth, Yield and Quality Forage Maize (zea mays L.). MSc. Thesisis, Faculity of Agriculture, University of Khartum, Sudan

Getinet Assefa, Fekede Feyissa and Abreham Gebeyehu. 2003. Effect of manure and nitrogen fertilization on establishment, herbage yield and seed productivity of perennial grasses. Proceedings of the 10th annual 
conference of the Ethiopian Society of Animal Production (ESAP) held in Addis Ababa, Ethiopia, August 21-23, 2003.

Manaye, T., Tollera, A. and Zewdu, T. 2009. Feed intake, digestibility and body weight gain of sheep fed Napier grass mixed with different levels of Sesbania sesban. Livestock Science 122: 24-29.

Mohammed, G.G. 1990. Effect of Nitrogen and Phosphorus Fertilizers on Growth and Yield of Some Grasses and Leguminous Forages. MSc. Thesis . Faculity of Agriculture, University of Khartum, Sudan

Saad, H.H. 2009. Evaluation of Nitrogen Fertilizers on Quality and Quantity of Rhodes Grass (Chloris gayana L. Kunth). M.Sc. Thesis. Faculty of Agriculture Studies, Sudan University of Science and Technology, Sudan

Valenzuela, H. and Smith, J., 2002. Rhodes grass. Univ. Hawaii, CTAHR Ext. Service, Sustainable Agriculture Cover Crops. SA-CC-3, Manoa, Hawaii 